\title{
Second World War conflict archaeology in the forests of north-west Europe
}

\author{
David G. Passmore ${ }^{1,{ }^{*}}$, Stephan Harrison ${ }^{2} \&$ David Capps Tunwell ${ }^{3}$
}

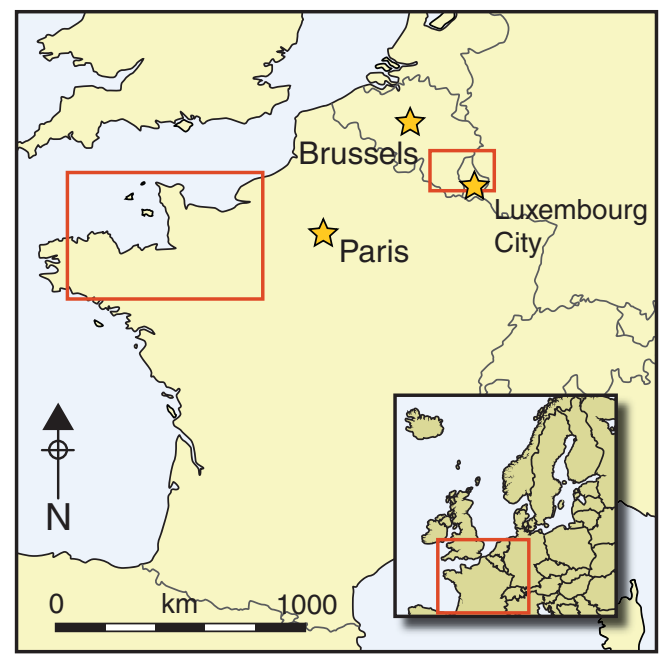

Concrete fortifications have long served as battle-scarred memorials of the Second World War. The forests of north-west Europe, meanwhile, have concealed a preserved landscape of earthwork field fortifications, military support structures and bomb-and shell-craters that promise to enhance our understanding of the conflict landscapes of the 1944 Normandy Campaign and the subsequent battles in the Ardennes and Hürtgenwald forests. Recent survey has revealed that the archaeology surviving in wooded landscapes can significantly enhance our understanding of ground combat in areas covered by forest. In particular, this evidence sheds new light on the logistical support of field armies and the impact of Allied bombing on German installations.

Keywords: Second World War, Normandy Campaign, Ardennes Offensive, conflict archaeology, field fortification, bomb-crater, logistics depot, battlefield

Supplementary material is provided online at http://antiquity.ac.uk/projgall/passmore342

\section{Introduction}

The archaeology of the Second World War (WW2) in north-west Europe is dominated by concrete and brick. From remote pillboxes and anti-tank cubes (Osborne 2004) to the extensive casemates and bunkers of the Atlantic Wall (Zaloga 2007) and the massive flak towers and air-raid shelters in German cities (Richardson 2008), hardened structures form the most conspicuous and enduring landscape legacy of WW2 conflict. Some of these structures have survived because they have been deliberately incorporated into the heritage inventory, perhaps through achieving a particular resonance at important battlefield sites

1 Department of Geography, University of Toronto (Mississauga), 3359 Mississauga Road, Mississauga, ON L5L 1C6, Canada

College of Life and Environmental Sciences, University of Exeter, Cornwall Campus, Penryn TR10 9EZ, UK

Lieu Dit Le Point Du Jour, 61140 La Chapelle d'Andaine, France

Author for correspondance (Email: david.passmore@utoronto.ca) 
Table 1. Selected WW2 site types in Britain (after Dobinson et al. 1997; Saunders 1998; Schofield 2001).

\author{
Anti-aircraft defences \\ Airborne landing precautions \\ Airfields \\ Airfield defences \\ Beach batteries \\ Coastal batteries and forts \\ Civil defence (air-raid shelters) \\ Bombing decoys \\ Radar sites \\ Experimental establishments \\ Factories \\ Observation posts \\ Anti-invasion defences (including pillboxes, road blocks, anti-tank ditches) \\ Resistance cells \\ Operation Diver sites \\ Operation Overlord preparatory sites (including Mulberry harbour construction sites, \\ maintenance and repair areas, embarkation sites)
}

(e.g. the Normandy D-Day beaches), or where they have subsequently facilitated alternative, non-military uses (e.g. Schofield 2004). More commonly, many have survived because they have proved difficult to remove or offer no impediment to modern land-use. Concrete and brick may also still bear the legacy of battle damage associated with gunfire or aerial bombing (Lynch \& Cooksey 2007), and in some cases such buildings have also achieved a measure of legislative protection. As the archaeological community has been developing an increasing interest in twentieth-century conflict archaeology (Schofield 2005; Lynch \& Cooksey 2007; Moshenska 2013), such structures have become the primary focus of survey and documentation of WW2 landscapes (e.g. Dobinson et al. 1997). Indeed, parts of northwest Europe-notably Britain —now have a well-developed classification of military sites and structures (Table 1; Saunders 1998), and many of these have achieved protection as historic monuments.

Concrete and brick constitute only part of the conflict landscape of north-west Europe, however. The nature of ground combat operations in the western theatre of WW2 militated against the development of semi-permanent and extensive networks of trench and bunker systems that typify the western European WW1 battlefield; earthwork field fortifications for shelter and combat were, however, routinely dug by front-line and support troops. In combination with shell- and bomb-craters, these will have formed a substantial part, if not the majority, of the immediate battlefield legacy. However, the detailed topography of such landscapes has rarely survived post-war reconstruction, landscaping and agricultural activity. Consequently, there are very few examples of field fortifications and cratered terrain in the published archaeological record, and they are seldom featured in academic or popular battlefield guides; visitors using Sutton Publishing's 2004 'Battle Zone Normandy' series (edited by Simon Trew) to navigate the beachhead and inland battlefield landscapes of the

(C) Antiquity Publications Ltd. 
Normandy Campaign, for example, will find that mention of extant shell-craters is limited solely to the preserved landscape at Pointe du Hoc (Badsey \& Bean 2004).

In this paper, we advocate a rebalancing of the WW2 archaeological research agenda in north-west Europe by highlighting the hitherto little-appreciated geographical setting where contemporary earthworks and cratered terrain have had the potential to survive through to the present-the region's historic forests and woodlands. The prospects for preservation of field fortifications have been previously identified by a pilot study in the Ardennes forests of Belgium (Passmore \& Harrison 2008); further examples of battlefield remains and military activities in forested settings are documented in publications on work in the Savernake Forest, England (Crutchley et al. 2009), the Hürtgenwald Forest, Germany (Rass \& Lohmeier 2011), and also in Finland (Seitsonen \& Herva 2011). More recently the authors have demonstrated extensive preservation of major German logistics depots in the Forêt domaniale des Andaines, Normandy (Passmore et al. 2013; Capps Tunwell et al. in press). This paper aims to build on this work by illustrating the nature, extent and research potential of WW2 conflict archaeology in forested parts of north-west Europe, with particular reference to two distinctive types of non-hardened military landscape; first, those that witnessed ground combat and have a legacy of improvised field fortifications, and second, landscapes associated with the logistical support of field armies.

\section{Geographical scope and methods}

Previous investigations of Ardennes field fortifications by the authors combined a fieldwork programme with published accounts of WW2 battlefield archaeology, heritage sites and contemporary aerial photographs (Passmore \& Harrison 2008). For this paper, we have extended the range of field fortification survey by reviewing: i) academic literature on conflict archaeology and heritage sites; ii) internet-based searches for descriptions and images of forest-based battlefields and military earthworks; and iii) examples of heritage trails and associated documentation that have a WW2 focus. These searches provided the basis for fieldwalking to verify the nature and context of archaeological survival. The geographical scope of the survey extended over several key battlegrounds of the western European theatre of operations between June 1944 and February 1945, including north-west France, the Ardennes forests of Belgium, Luxembourg and Germany, the Hürtgenwald and Reichwald forests of western Germany and woodlands around the Arnhem region of the Netherlands (Figure 1).

Forest survey in north-west France has also incorporated a study of German Army (Heer) logistics depots in the Forêt domaniale des Andaines (Passmore et al. 2013; Capps Tunwell et al. in press). Here we report on an extension of this work that has sought to establish the geography of munitions and fuel depots and their archaeological potential in woodlands across an area of north-west France that witnessed the Normandy Campaign; this area includes the regions of Basse Normandie, Haute Normandie and Bretagne, northern parts of Pays de la Loire and Centre, and the eastern extent of Île-de-France and Picardie (Figure 1). The location and function of logistics depots have been identified primarily using archive documents and aerial photographs (see below), supplemented by field visits and sample surveys at selected sites in order to assess the degree of survival of depot structures and 


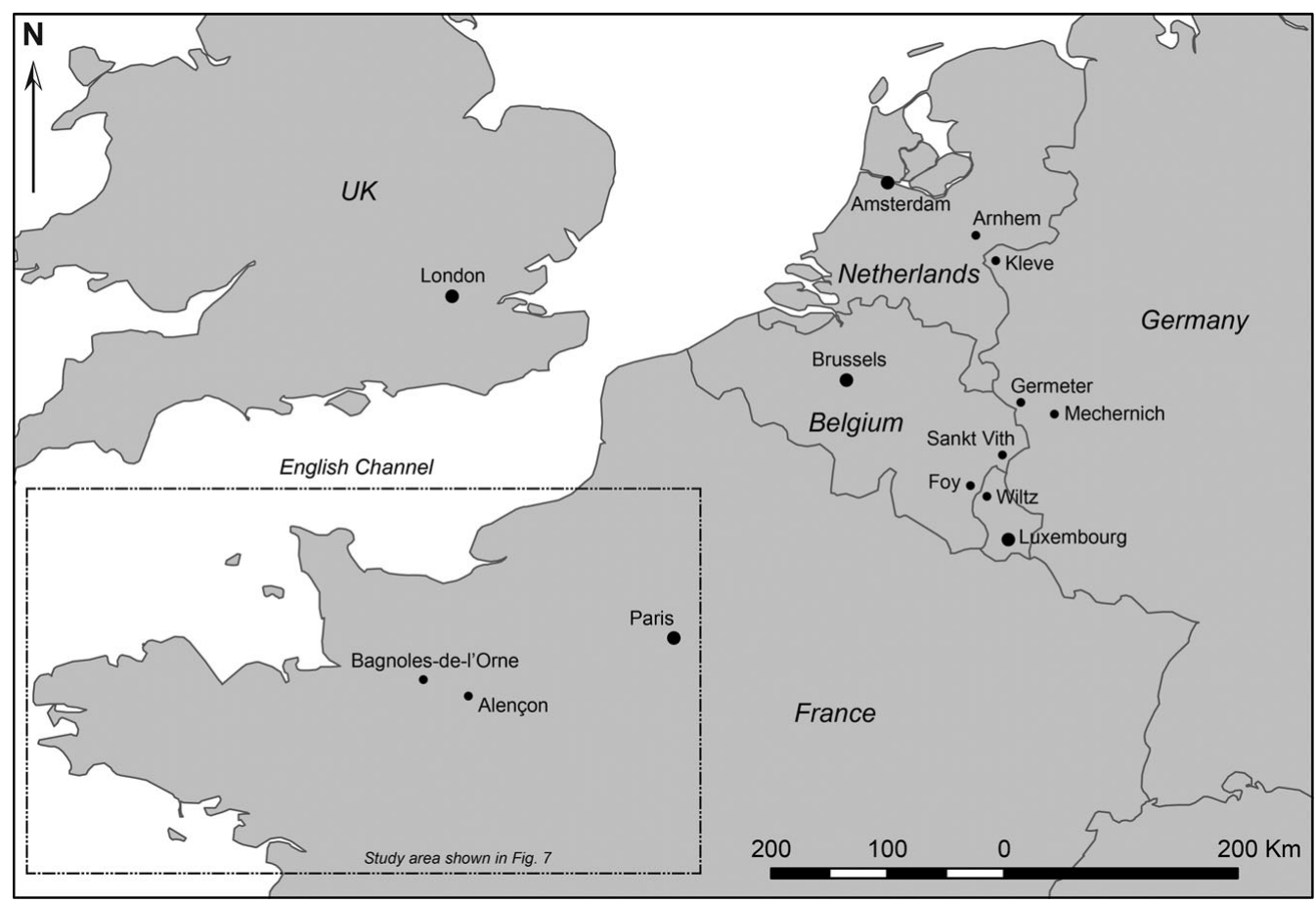

Figure 1. Map of north-west Europe showing study areas and sites mentioned in the text.

bomb-craters. Non-invasive field survey of extant features at logistics depots has focused on the location, planform morphology and relief of earthworks on the forest floor; features were classified according to the typology developed by Passmore et al. (2013), which reflects function, planform dimensions, the primary mode of construction and the relationship of features to nearby roads or tracks. Integration and analysis of field survey data, archive maps and aerial photographs has been facilitated using a GIS framework.

\section{Field fortifications in north-west European forests}

Small unit actions throughout north-west Europe regularly took place in localised wooded settings that offered cover and concealment; but it is the extensive forests of the Ardennes, in the border region of Belgium, Germany and Luxembourg, and the neighbouring Hürtgenwald area of western Germany (Figure 1), that are most widely recognised for hosting large-scale combat operations in woodland terrain (Miller 1995; Cavanagh 2001). It is these areas that provide the only three examples of mapped (and differentiated) field fortifications known to the authors; below we illustrate these case studies in order to emphasise the preservation potential of combat landscapes in this region.

The first two examples are associated with the German Ardennes Offensive ('Wacht am der Rheine', or the Battle of the Bulge) in December 1944-January 1945. In the Sankt Vith area of eastern Belgium (Figure 1) a forested area of $1.4 \mathrm{~km}^{2}$ preserves at least 116 discrete features that were assigned to a threefold typology encompassing large

(C) Antiquity Publications Ltd. 

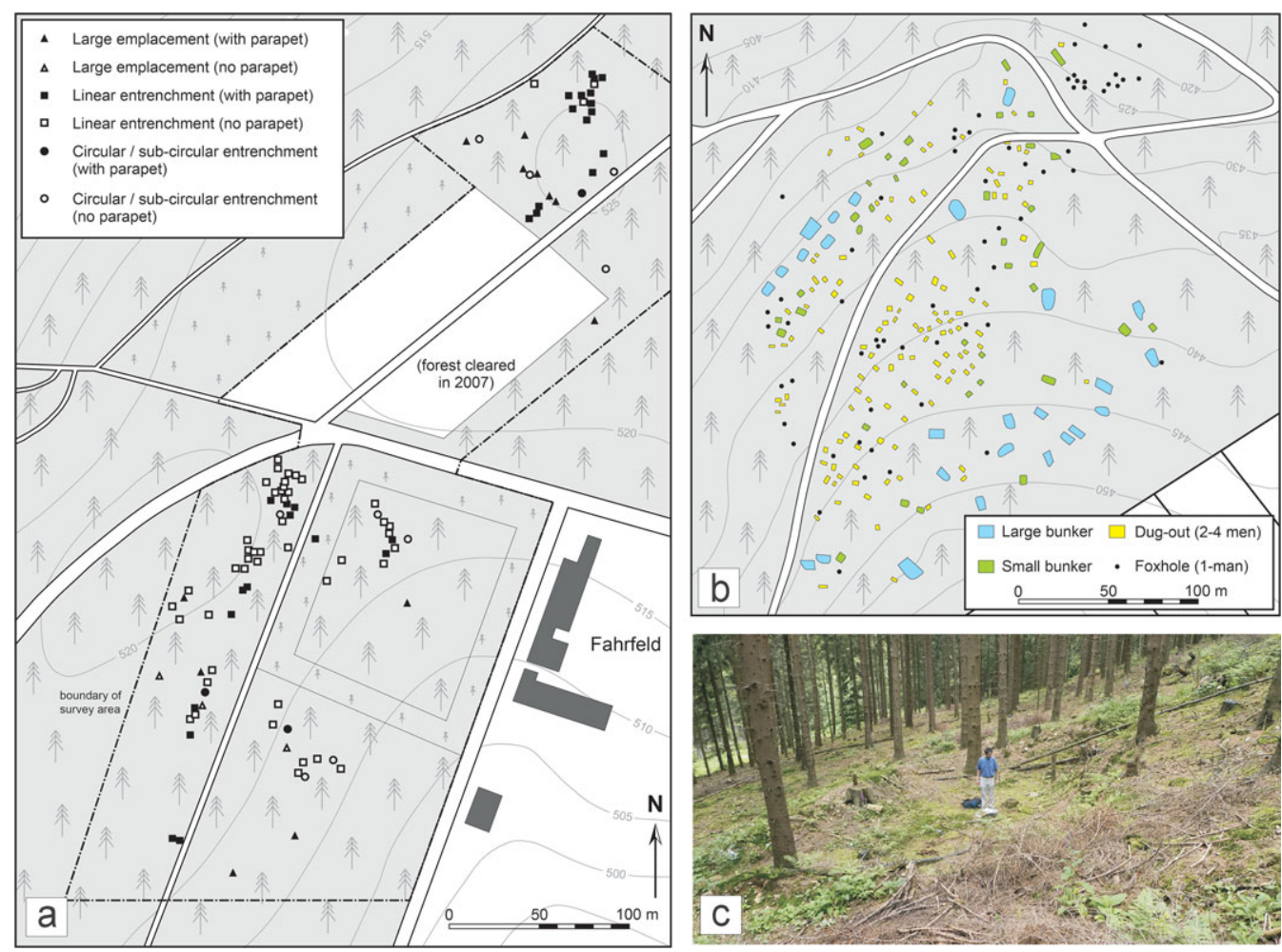

Figure 2. a) Map of the Prumerberg study site, St. Vith, Belgium, showing location and classification of US Army field fortifications (after Passmore \& Harrison 2008); b) map of the Hürtgenwald forest near Germeter, western Germany, showing location and classification of US Army field fortifications (after Wegener 2011); c) large bunker at the Germeter study site.

emplacements, rectilinear entrenchments and circular and sub-circular entrenchments or shell-craters (Figure 2a) (Passmore \& Harrison 2008). This archaeological data was shown to permit an analysis of the form and disposition of features in the context of field fortification doctrine, documented accounts of combat in the area and the terrain and landscape setting (Passmore \& Harrison 2008). The second example is the battleground at Schumanns Eck, near Wiltz in Luxembourg (Figure 1), which saw two weeks of intensive combat between the US $26^{\text {th }}$ Infantry Division and German $9^{\text {th }}$ Volksgrenadier Division. Today, the site has the status of a 'National Liberation Memorial' and features a commemorative monument, detailed information and interpretative boards and a waymarked memorial woodland trail (the 'Path of Remembrance 1944-1945') that guides the visitor through a landscape of abundant and, for the most part, well-preserved foxholes and trenches (Figure 3a-d). While the information presented does not represent an exhaustive survey of features in the vicinity of the trail, it nevertheless constitutes a rare example of a survey that both maps and differentiates field fortifications (including trenches and foxholes), as well as shell-holes and bomb-craters.

To the north-east of the Ardennes battlefields, the US assaults through the Hürtgenwald in late 1944 are a lesser known part of operations in north-west Europe, but nevertheless are notable for having received archaeological attention (Rass \& Lohmeier 2011), and are

(C) Antiquity Publications Ltd. 

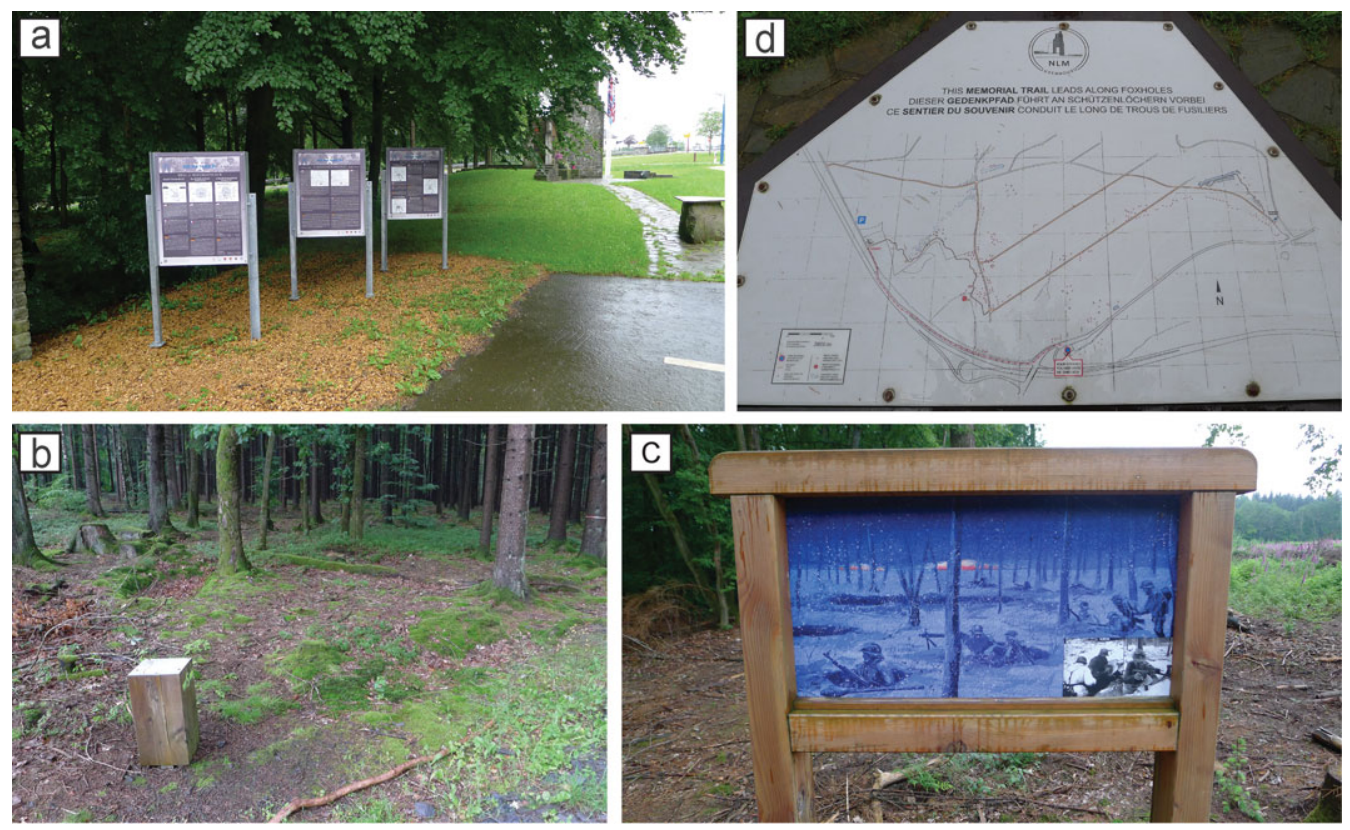

Figure 3. National Liberation Memorial and woodland memorial trail at Schumanns Eck, near Wiltz, Luxembourg (see Figure 1). a) Battlefield information boards at the Memorial car park; b) Memorial trail waypoint; note foxhole at base of tree to centre-left; c) interpretative image and photographs on the Memorial trail; d) map of the Memorial trail (visible to far right of 3 a) showing locations of foxholes and trenches.

the location of some especially well developed military heritage trails and associated tourist information (Figure 4). This development owes much to the efforts of regional tourism, education and archaeological bodies (especially the Konejung Foundation and the LVR Office of Archaeological Excavation in the Rhineland), and has a particular focus on the concrete bunkers and other hardened fortifications of the West Wall (e.g. Wegener 2006). However, the Hürtgenwald Archaeological Trail, located in the wooded valley of Weisser Weh, west of the village of Germeter (Figure 4), is similarly informed by a detailed survey of field fortifications in a $0.5 \mathrm{~km}^{2}$ area of woodland $400 \mathrm{~m}$ west of the village (Konejung Stiftung Kultur 2011; Figure 2b \& c). This survey has mapped over 250 discrete earthworks and differentiates between large and small bunkers, dugouts suitable for two to four men and one-man foxholes (Figure $2 \mathrm{~b} \& \mathrm{c}$ ). The larger bunkers at this location lack interconnecting communications trenches that are characteristic of German defensive field fortification doctrine (Rottman 2004), and the site is therefore interpreted as an American position (Wegener 2011), most likely that of the $1^{\text {st }}$ Battalion, $112^{\text {th }}$ Infantry Regiment $\left(28^{\text {th }}\right.$ Infantry Division), positioned just behind the front line on 3 November 1944 and immediately prior to the ill-fated attack on Schmidt (Miller 1995).

Detailed mapping of this nature not only illuminates the military history of specific combat events and operations-what Rass and Lohmeier (2011) term 'micro-history'but also opens up the possibility of wider comparisons between field fortification practice in differing physical and operational contexts, and between opposing forces. Survey by

(C) Antiquity Publications Ltd. 
the authors has documented field fortifications in many other locations in the wider Hürtgenwald and Ardennes study areas described above, as well as parts of the Reichswald Forest in north-west Germany, wooded

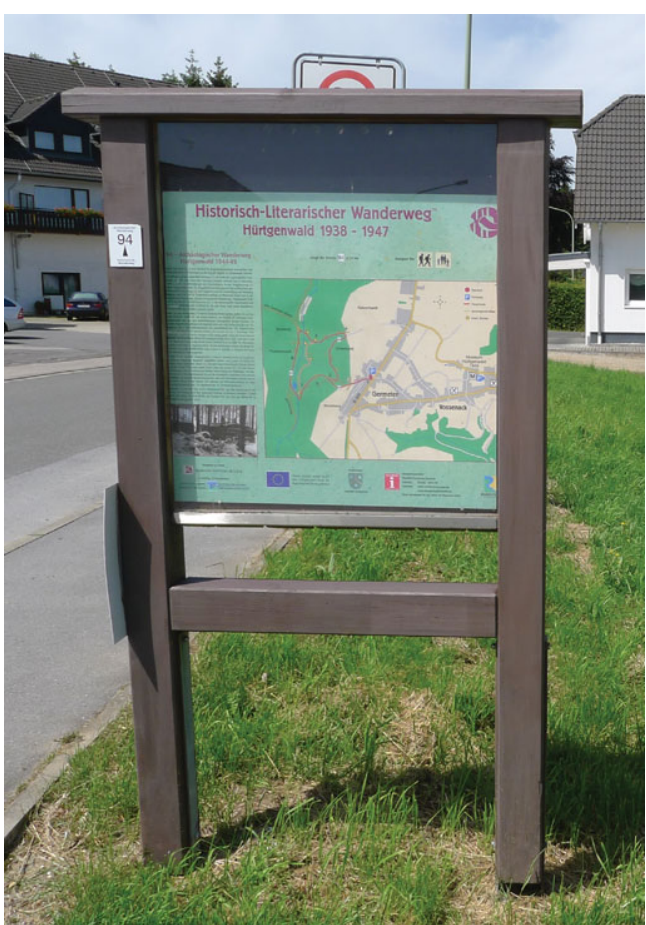

Figure 4. Map and interpretative board for the Hürtgenwald Archaeological Trail, Germeter, western Germany. battlefields around Arnhem (Netherlands) (Figure 5) and in several parts of the Normandy region (unpublished data). We therefore argue that there is considerable scope for further battlefield survey and analysis in the forests of western Europe and no doubt also in the wooded battlefields of the Eastern Front.

\section{Logistics and supply in the Normandy Campaign}

The difficulties in the supply of munitions and fuel experienced by German forces in Normandy, in the face of overwhelming Allied air superiority, have been widely acknowledged as being a significant factor in their defeat (e.g. Vogel 1994). Yet, with the notable exception of aspects of Hart's (1996) analysis of primary source material, the supply depots themselves have not been subject to detailed historical analysis nor, until recently, archaeological evaluation. In

this respect the recent reporting of exceptionally well preserved earthworks associated with fuel, munitions and rations depots in the historic forest landscape of the Forêt domaniale des Andaines (Passmore et al. 2013; Capps Tunwell et al. in press) is of archaeological significance, not least because the frequent German practice of siting logistics depots in wooded locations established the same long-term preservation potential as is evident for field fortifications.

In seeking to extend this investigation across the wider region we have prioritised the identification of fuel and munitions depots in forested locations; the progress reported here therefore excludes sites that are believed to be exclusively urban. The initial site inventory was extracted from the diaries of the German $7^{\text {th }}$ Army Quartermaster (located at the National Archives Research Agency, Maryland, USA) and augmented and cross-checked with reference to the Allied Tactical Target Dossiers and the records of the $9^{\text {th }}$ Air Force (Air Force Historical Research Agency, Maxwell Air Force Base, Alabama, USA). Potential forest sites were also assessed for evidence of bomb-cratering and areas cleared by fire and disposal activities during German abandonment of depots and post-war munitions clearance, using vertical aerial photographs dating between 1946 and 1952 and accessed via the Institute Géographique National (IGN). In some cases the image quality and degree of post-war

(C) Antiquity Publications Ltd. 

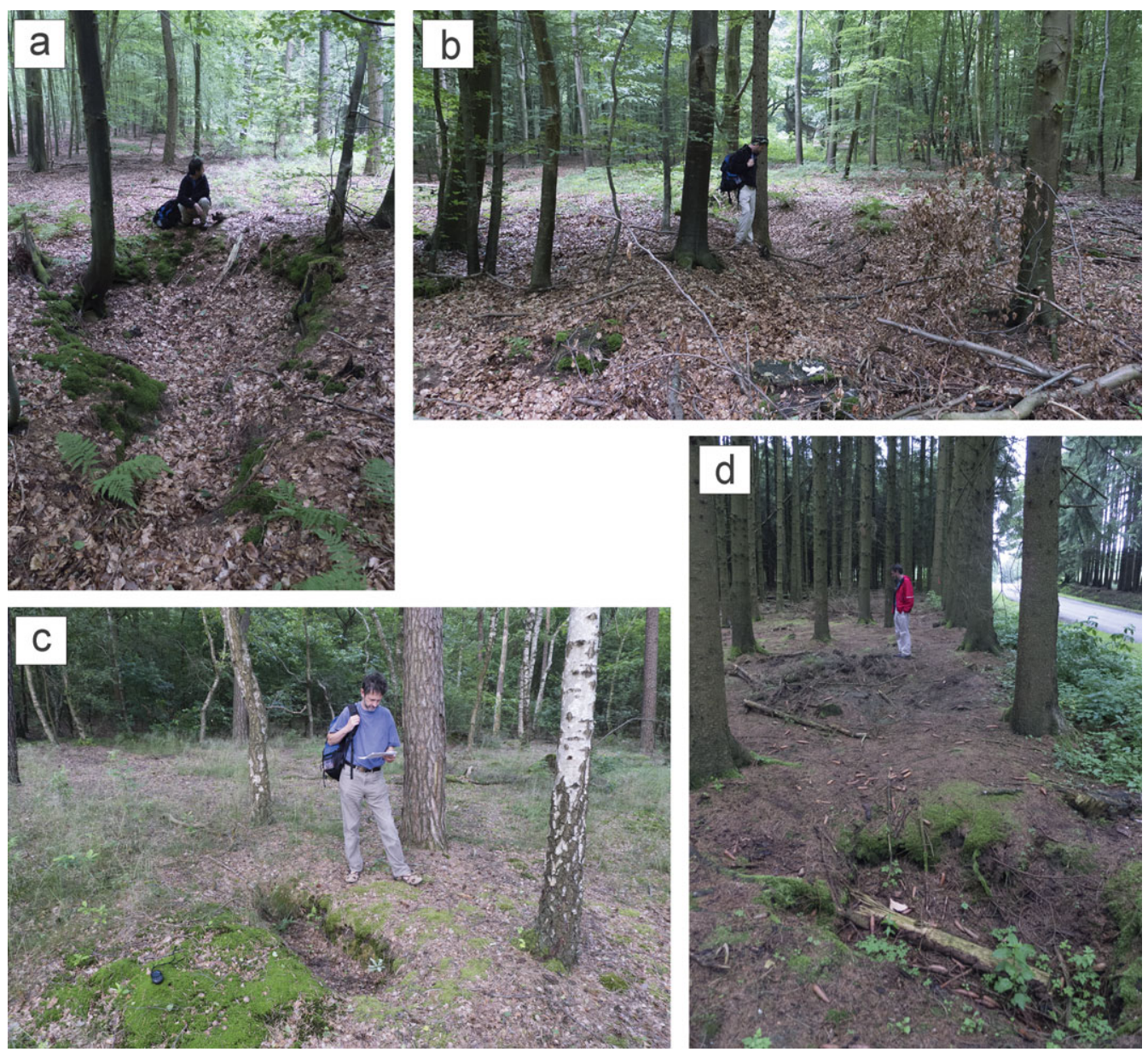

Figure 5. a \& b) Weapons pit and zig-zag trench in the Reichswald forest near Kleve, western Germany; c) slit trench in woods near Wolfheze, Arnhem, Netherlands; d) foxholes in woods near Foy, east of Bastogne, Belgium.

clearance and disturbance is sufficient to reveal individual munitions and fuel bunkers (Figure 6).

The geographical location, context and evidence base for fuel and munitions depots is summarised in Figure 7 below and Table S1 in the online supplementary material. This database will require updating as research work progresses and is especially likely to have overlooked relatively small and short-lived dumps associated with divisional stockpiling. Nevertheless, the inventory currently stands at a total of 63 forest-based logistics sites and demonstrates the considerable geographical spread of depot locations with sites positioned throughout the study area. Indeed, most of the larger historic forests in Normandy, and many smaller ones besides, appear to have been exploited to this end. The timespans of depot construction, use and destruction or closure vary greatly and have yet to be fully established, although the concentration of sites in the Caen-Falaise-Argentan region probably reflects the establishment of depots between June and August 1944 in response to the operational (C) Antiquity Publications Ltd. 

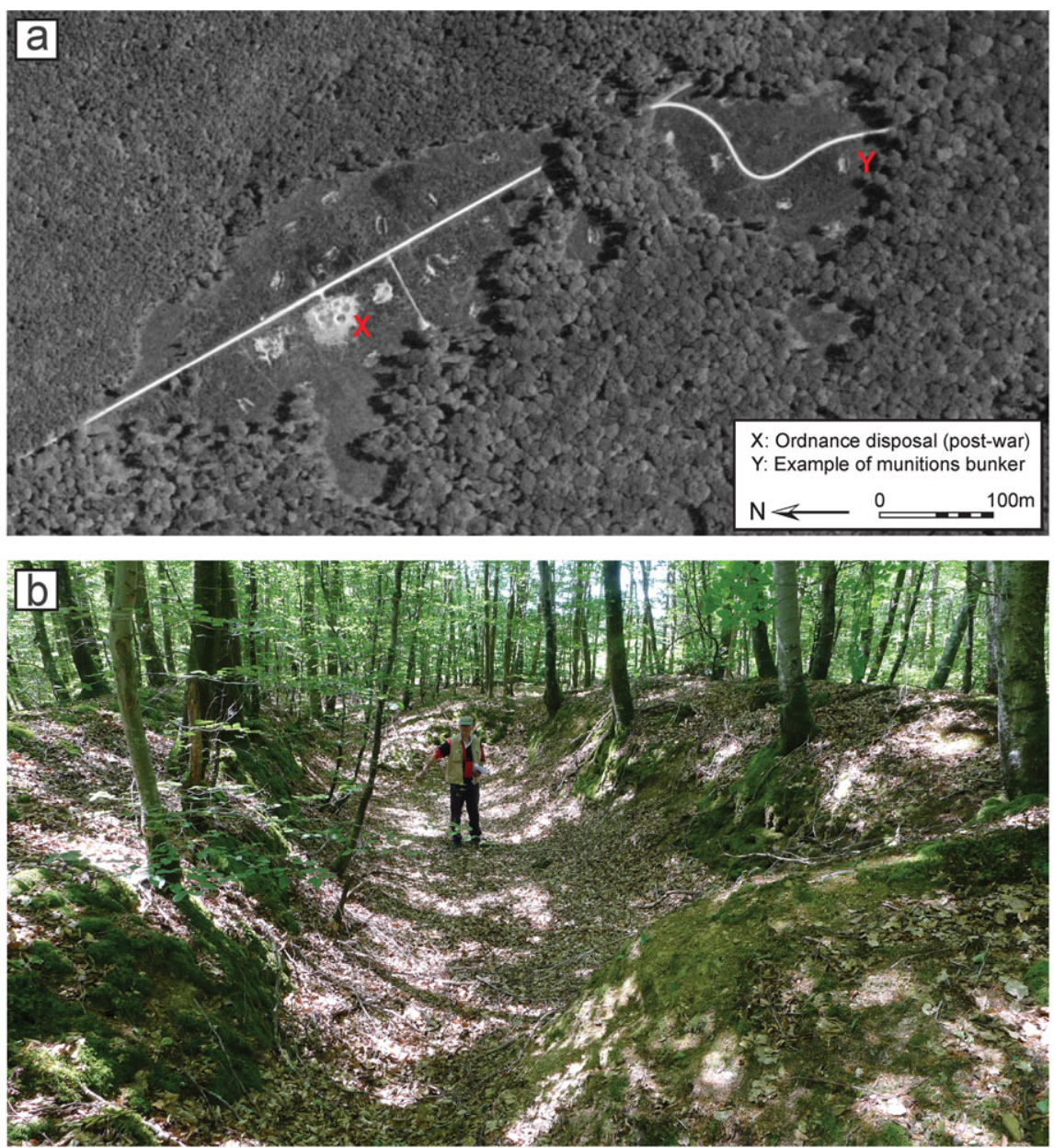

Figure 6. a) Vertical aerial photograph (IGNFC1417-0041_1949_F1417-1717_0439) of the Forêt domaniale de Perseigne near Ancinnes (Alençon), Normandy, showing areas of cleared woodland, evidence of post-1944 munitions disposal activity and munitions bunkers associated with Lager Monika on both sides of the forest road; b) photograph of munitions bunker at Location $Y$.

situation following D-Day. However, the $7^{\text {th }}$ Army records for the 5 June 1944 list a total of 18 fuel and 9 munitions depots in its area of north-west France, of which 16 were located in forests (Passmore et al. 2013; Figure 7 and Table S1). These records also establish the command hierarchy and reporting arrangements for $7^{\text {th }}$ Army depots at this time (Figure 7).

To date, seven sites have been visited for purposes of archaeological survey and in all cases the forest floors were found to preserve clear evidence of depot-related earthworks (Table S1). While some individual features bore evidence of demolition (conducted during abandonment of the depots) and post-war damage and disturbance, primarily as a result of forestry operations, road improvements and occasional informal (and illegal) excavations, the earthworks for the most part were found to be in a good state of preservation, with larger munitions bunkers exhibiting over $2 \mathrm{~m}$ of vertical relief (e.g. Figure 6). Full details

(C) Antiquity Publications Ltd. 


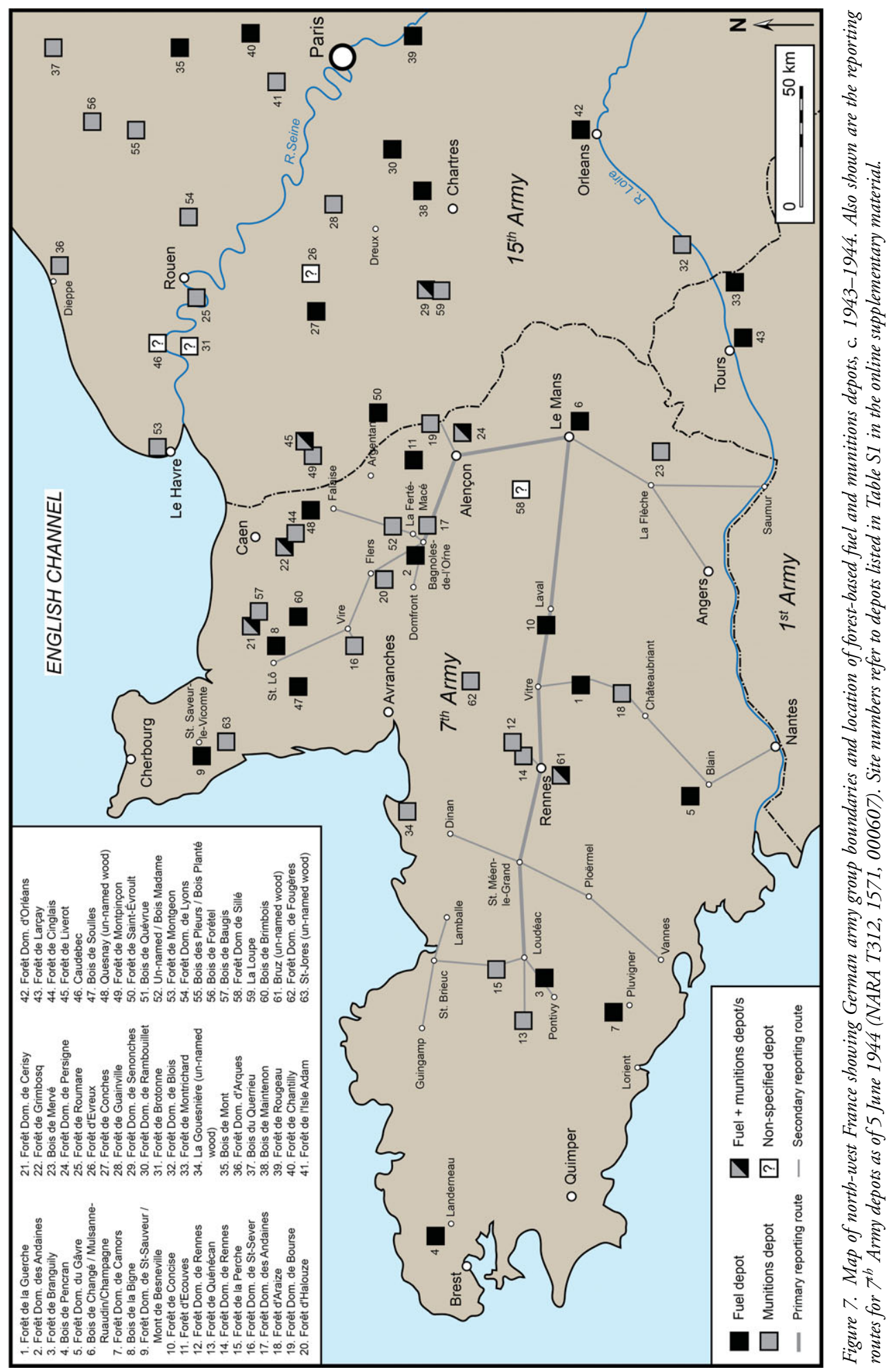

(C) Antiquity Publications Ltd. 


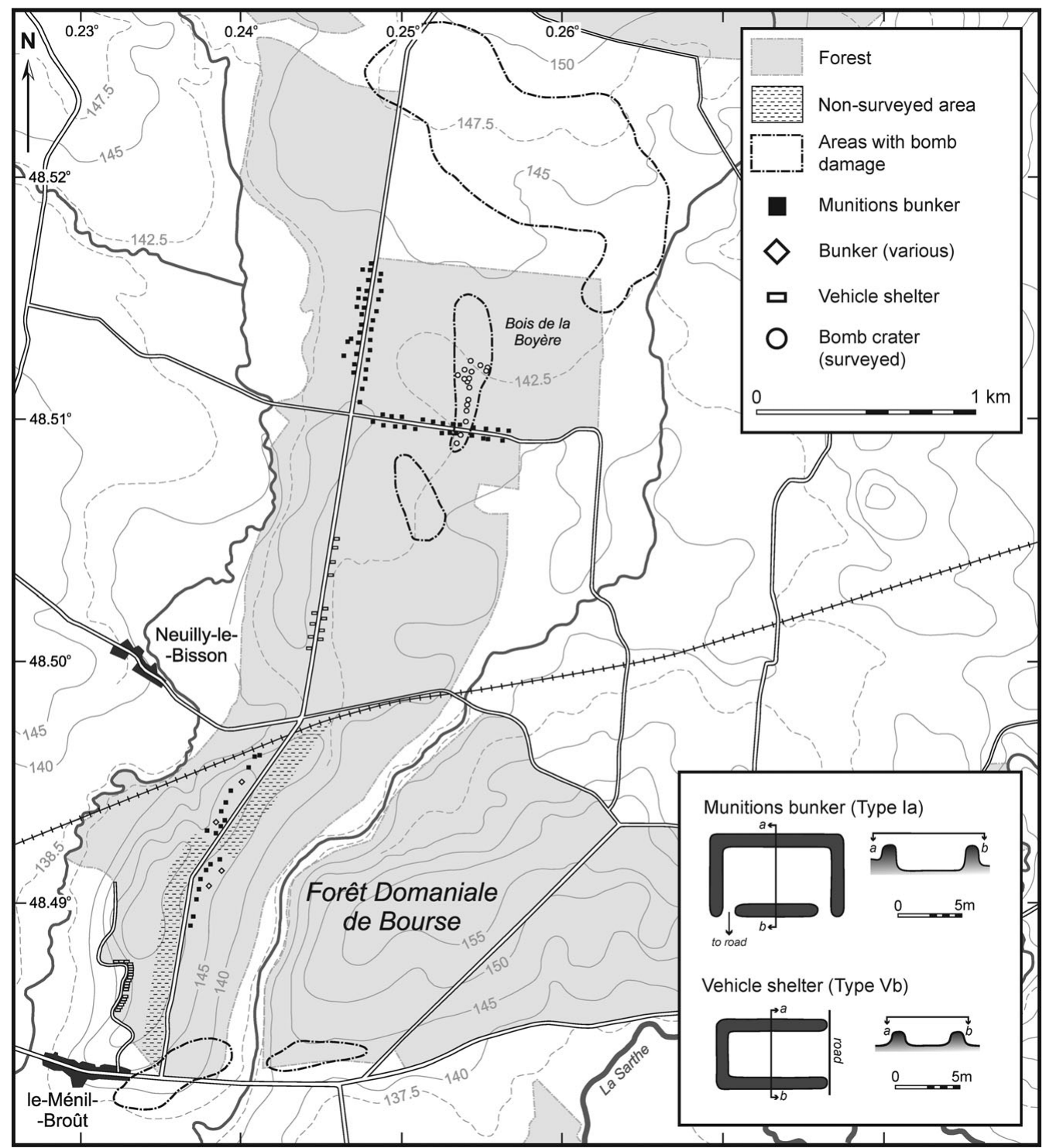

Figure 8. Map of the Forêt domaniale de Bourse near Le Ménil-Broût (Alençon), Normandy, showing surveyed locations of extant munitions bunkers and vehicle shelters associated with Lager Max munitions depot. Also shown are areas with evidence of bomb-craters and the locations of surveyed bomb-craters. Inset: schematic planforms and profiles of munitions bunkers and vehicle shelters in the study area. For map location see Figures 1 \& 2.

of the surveys will be forthcoming in follow-up papers, including a full survey of depot archaeology in the Forêt domaniale des Andaines (Capps Tunwell et al. in press); here we draw on a near-complete survey of Lager 'Max', located in the Forêt domaniale de Bourse near Le Ménil-Broût, $12 \mathrm{~km}$ north-east of Alençon (Figure 7), in order to illustrate the geography and character of a $7^{\text {th }}$ Army munitions depot (Figure 8).

(C) Antiquity Publications Ltd. 


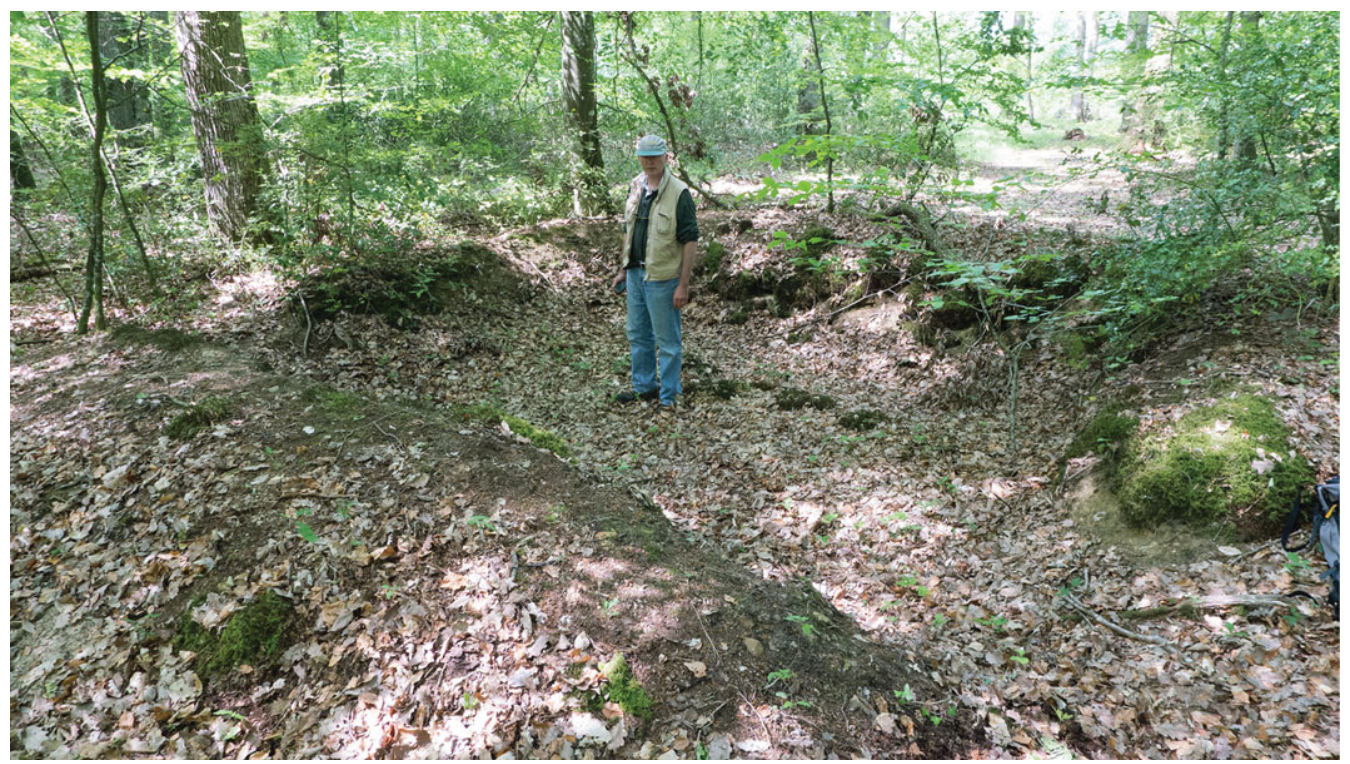

Figure 9. Photograph of Lager Max munitions bunker in the Bois de la Boyère, Forêt domaniale de Bourse, Normandy.

Munitions Lager 'Max' was one of nine depots administered by the $7^{\text {th }}$ Army in the Normandy region in early June 1944; on 1 June the depot was reported as holding 1417 tonnes of ordnance, amounting to 7.6 per cent of $7^{\text {th }}$ Army stocks (NARA T312, 1571, 000607; Passmore et al. 2013). Field evidence of depot facilities at Max includes at least 80 discrete munitions bunkers sited alongside $2.4 \mathrm{~km}$ of forest roads and not more than $2 \mathrm{~km}$ from the rail link to Alençon, which passes through the forest (Figures $8 \& 9$ ). It should be noted, however, that dense recent forest growth precluded access to approximately half of the roadside terrain in the southern part of the forest and the current audit probably underestimates the original depot provision. The majority of these features conform to the Type 1a (munitions) bunker class that has been described for Lager Martha in the Forêt domaniale des Andaines (Passmore et al. 2013; Capps Tunwell et al. in press; Figure 8) and when originally constructed were probably provided with planked timber walls, floors and timber roofs (NARA T312 R1562 0750). Max was also provided with two clusters of embanked roadside vehicle shelters, respectively located in the central part of the forest on either side of the main north-south road (12 features) and in the extreme south-west margin of the forest flanking a minor road extending north from Le Ménil-Broût (19 features) (Figure 8).

\section{Landscapes of bombing}

A striking outcome of survey in the Forêt domaniale des Andaines is the extensive survival of bomb-cratered terrain (Passmore et al. 2013), and this is currently being subjected to an in-depth analysis (Capps Tunwell et al. in prep. a \& b). Archaeological landscapes of Allied bombing are well preserved in other surveyed localities, and may even be a widespread feature of the regional woodlands (Table S1). In the vicinity of Lager Max (Forêt domaniale

(C) Antiquity Publications Ltd. 


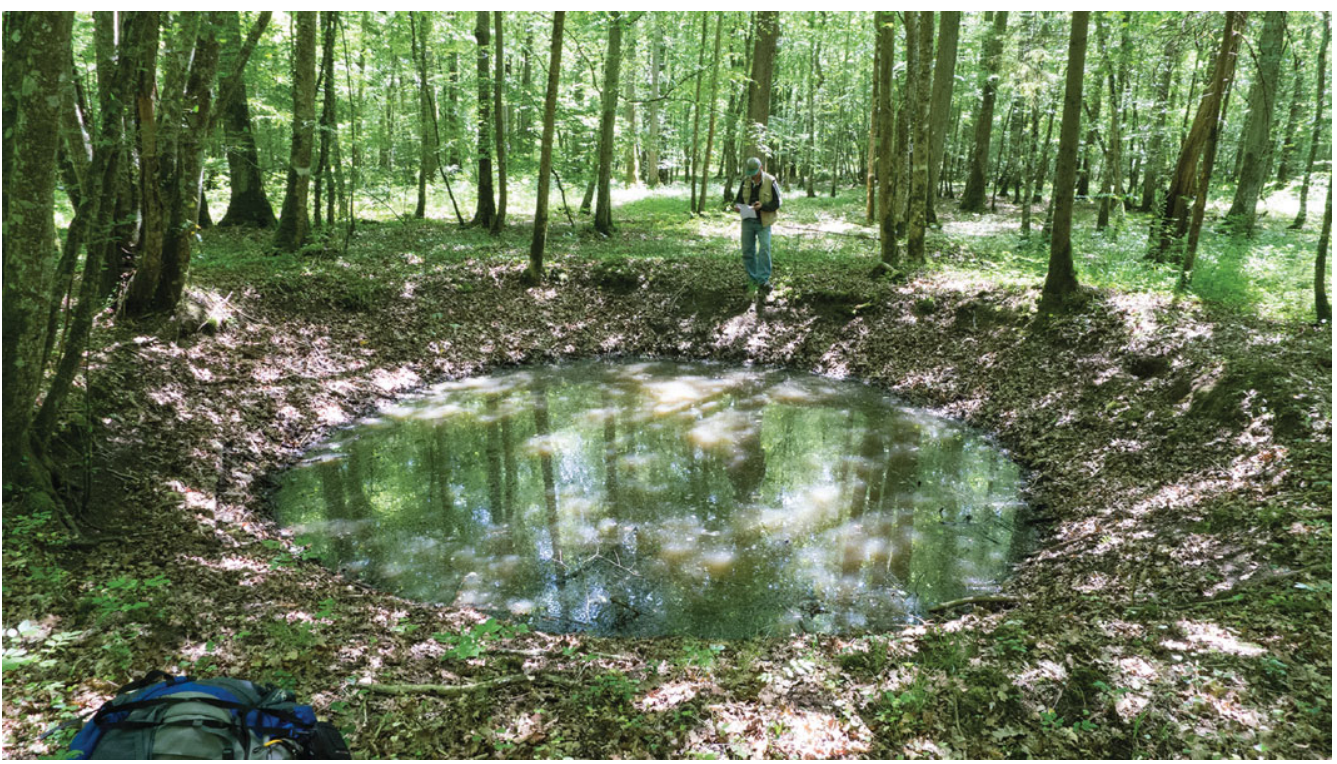

Figure 10. Photograph of bomb-crater in the Bois de la Boyère, Forêt domaniale de Bourse, Normandy.

de Bourse), for example, aerial photographs taken in 1949 show evidence of bombing in this locality in the form of cropmarks in open fields and as clusters of small canopy openings (occasionally with visible craters) in wooded parts of the study area (Figure 8). The largest area of bomb damage lies in the fields immediately north of the forest margin, which in June 1944 were part of the Luftwaffe's Essay airfield and which were bombed on 17 June 1944 by B-24 aircraft of the $486^{\text {th }}$ Bomb Group (Hennessy 1952). Today there is no visible evidence of this raid in the open landscape, but bombs impacting in the adjacent forest are marked by especially well preserved bomb-craters (Figure 10). Seventeen examples of extant craters have been surveyed in the northern part of the forest (Bois de la Boyère) where they form a north-south array that intersects with munitions bunkers (Figure 8). At the time of survey most of these craters were partially filled with water or mud (Figure 10) and so records of crater depth are minimum estimates, but their surface diameters were reliably found to range between 4 and $10 \mathrm{~m}$ (Table S2 in online supplementary material). As no bomb exploded within $30 \mathrm{~m}$ of a munitions bunker, it is unlikely that this part of Lager Max suffered any significant damage.

\section{Discussion}

The emerging picture of the work reported above is of a wealth of archaeological landscape preservation in many wooded areas that witnessed combat or other military activity in WW2, and which, with further study, promises to illuminate even some of the most famous WW2 battlefields as well as the lesser-known aspects of the logistical support of field armies. Recognition that field fortifications and shell- and bomb-damaged terrain is more widely preserved than hitherto appreciated promises to expand greatly the inventory and scope of conflict archaeology that deals with the immediate impact of WW2 fighting

(C) Antiquity Publications Ltd. 
in north-west Europe. Thus, while Schofield's (2005) Combat Archaeology has done much to formalise and contextualise the archaeological study of twentieth-century conflict, it is interesting to note that of the broad range of material culture illustrated therein, relatively few examples-notably spent ordnance, damaged building fabric, aircraft crash sites and sunken vessels_can claim to constitute the direct archaeological signature of combat. It is therefore the woodlands of north-west Europe that stand to provide the WW2 equivalent of the well-preserved, studied and protected battle-scarred landscapes of WW1's Western Front.

These landscapes also have much to contribute to wider research agendas, including those focused on heritage and memory (e.g. Rass \& Lohmeier 2011), military geography (e.g. Woodward 2014) and historical accounts and narratives of conflict (e.g. Passmore \& Harrison 2008), as well as complementing studies of the environmental impact of combat (e.g. Steinweg \& Kerth 2013). Here we draw attention to two particular research themes that are the focus of ongoing work.

First, the problems faced by the German military logistics effort during the Normandy Campaign are widely recognised in the military history literature (e.g. Zetterling 2000; Reardon 2002), but there have been few attempts to build on the archival analysis reported by Hart (1996), and much remains to be clarified with respect to the scale, character and military geography of logistics efforts in the Normandy Campaign. Forests are likely to play a key role in this undertaking as wooded locales with good transport links in the Normandy region-and possibly elsewhere in the hinterland of the Atlantic Wall—are likely to have hosted Heer fuel, munitions and rations depots. Furthermore, and accepting that our present audit for the most part demonstrates potential rather than proven archaeological survival, it is likely that many of these sites will retain visible evidence of logistics earthworks and bomb-craters, and there is a possibility that some will exhibit near-complete archaeological landscape survival for this period. Ongoing work is focusing on refining knowledge of the design, operation and geographical distribution of supply depots both before and especially after 6 June 1944. At the depot and feature scale there is a need to develop a robust typology of storage bunkers that can be linked to specific functions and capacity. Furthermore, although this effort is currently focusing on the Normandy region, reconnaissance survey by the authors in woodlands near Mechernich, $29 \mathrm{~km}$ inside the western German border (Figure 1), has identified munitions bunkers similar to those described above and which most probably reflect stockpiling of ammunition in advance of the 1944 Ardennes Offensive (unpublished data). Accordingly, we suggest this approach is likely to be fruitful in other parts of north-west Europe.

Second, archaeological analysis has much to offer an evaluation of the strategy, effectiveness and landscape impact of Allied bombing of the German logistics network, especially where documentary evidence is ambiguous or fragmentary. Hart's (1996) analysis of the difficulties faced by German forces in transporting fuel and munitions during the Normandy Campaign remains the most detailed available, but landscape evidence in the Forêt domaniale des Andaines is beginning to challenge some of his assumptions regarding Allied bombing of the depots themselves (Capps Tunwell et al. in prep. a \& b). Furthermore, the landscape evidence of the 17 June 1944 bombing of Essay demonstrates the potential for combining bomb-crater surveys with the detailed documentation of specific air raids.

(C) Antiquity Publications Ltd. 
Gaffney et al. (2004) have previously recognised that the archaeological evaluation of shellcraters may yield insights into the effectiveness of Allied bombing and shelling strategies, although in this case they were referring to remote-sensing of sub-surface features for assessing parameters such as angle of strike and ferrous object disposition. Here we note that extant bomb-craters in forested terrain are liable to be especially receptive to analyses linking crater size, depth and disposition to records of bomb loads, raid height and bomber flight patterns (Capps Tunwell et al. in prep. a).

\section{Conclusions}

Writing in 1994-the year of the fiftieth anniversary of D-Day-Chippindale's Antiquity editorial observes that "it is the number and mass of objects that make one aware of the material differences of twentieth-century warfare" (1994: 478). Chippindale would no doubt recognise the vast majority of objects specific to WW2 that have been documented since. But nearly 20 years on, it would appear that we have significantly underestimated the "quantity of stuff" (Chippindale 1994: 478) that remains to be documented in the conflict landscapes of WW2 Europe. In hosting such a well-preserved earthwork legacy of constructional features and explosive impacts, forest and woodland environments stand as a unique resource in the context of WW2 battlefields in north-west Europe. This is true not only in terms of the quantity of material, but also in complementing the concrete and brick of widely recognised conflict landscapes with more ephemeral battlefield and bombscape archaeology. As we witness the seventieth anniversary of D-Day and the liberation battles of north-west Europe, it is to be hoped that the archaeological community will follow the example set by excavation and restoration work on the trenches and bunker systems of WW1; we argue here that regional forests offer an excellent opportunity to do so.

\section{Acknowledgements}

The authors wish to thank Iain Banks and Christoph Rass for their helpful and constructive comments.

\section{References}

Badsey, S. \& T. BeAN. 2004. Omaha Beach. Stroud: Sutton.

Capps Tunwell, D., D.G. Passmore \& S. Harrison. In press. Landscape archaeology of World War Two German logistics depots in the Forêt domaniale des Andaines, Normandy, France. Journal of Historical Archaeology.

- In preparation a. The archaeology of WW2 bombing in the Forêt domaniale des Andaines, Normandy, France. Submitted to the Journal of Field Archaeology.

- In preparation b. A witness in the landscape: Allied bombing of the Forêt domaniale des Andaines and the Normandy Campaign, France, 1944. Submitted to War in History.
CaVanagh, W.C.C. 2001. A tour of the Bulge Battlefield. Barnsley: Pen \& Sword.

Chippindale, C. 1994. Editorial. Antiquity 68: 477-88.

Crutchley, S., F. Small \& M. Bowden. 2009. Savernake Forest: a report for the National Mapping Programme (English Heritage Research Department Report 29). Portsmouth: English Heritage.

Dobinson, C., J. LAKE \& A.J. SCHOFIELD. 1997. Monuments of war: defining England's $20^{\text {th }}$-century defence heritage. Antiquity 71 : 288-99.

Gaffney, C., J. Gater, T. Saunders \& J. Adcock. 2004. D-Day: geophysical investigation of a World War II German site in Normandy, France. Archaeological Prospection 11: 121-28. http://dx.doi.org/10.1002/arp.233 
HART, R.A. 1996. Feeding Mars: the role of logistics in the German defeat in Normandy, 1944. War In History 3: 418-35. http://dx.doi.org/10.1177/ 096834459600300404

Hennessy, J. 1952. Tactical operations of the Eighth Air Force, 6 June 1944-8 May 1945 (United States Air Force Historical Studies 70). Maxwell (AL): Air Force Historical Research Agency.

Konejung Stiftung Kultur. 2011. Archäologischer Wanderweg Hürtgenwald 1944-45 (Flyer 94). Vettweiss-Müddersheim: Konejung Stiftung Kultur. Available at: http://www.rureifel-tourismus.de/ fileadmin/data/Downloads/Flyer-Archaeologischer. pdf (accessed 10 June 2014).

LYNCH, T. \& J. COOKSEY. 2007. Battlefield archaeology. Stroud: Tempus.

Miller, E.G. 1995. A dark and bloody ground: the Hürtgen Forest and the Roer River dams, 1944-1945. College Station: Texas A\&M University Press.

MoshensKa, G. 2013. The archaeology of the Second World War: uncovering Britain's wartime heritage. Barnsley: Pen \& Sword Archaeology.

Osborne, M. 2004. Defending Britain: twentieth-century military structures in the landscape. Stroud: Tempus.

Passmore, D.G. \& S. Harrison. 2008. Landscapes of the Battle of the Bulge: WW2 field fortifications in the Ardennes forests of Belgium. Journal of Conflict Archaeology 4: 87-107. http://dx.doi.org/10.1163/ $157407808 \times 382773$

Passmore, D.G., D. Capps Tunwell \& S. Harrison. 2013. Landscapes of logistics: the archaeology and geography of WW2 German military supply depots in central Normandy, NW France. Journal of Conflict Archaeology 8: 165-92. http://dx.doi.org/ 10.1179/1574077313Z.00000000025

RASS, C. \& J. LOHMEIER. 2011. Transformations: post-battle processes on the Hürtgenwald battlefield. Journal of Conflict Archaeology 6: 179-99. http://dx.doi.org/10.1179/ 157407811 X13160762840242

REARDON, M.J. 2002. Victory at Mortain: stopping Hitler's Panzer counteroffensive. Lawrence: University Press of Kansas.

RICHARDSON, S. 2008. Destruction preserved: Second World War public air-raid shelters in Hamburg, in L. Rakoczy (ed.) The archaeology of destruction: 6-28. Newcastle-upon-Tyne: Cambridge Scholars.
RoTTMAN, G.L. 2004. German field fortifications 1939-45. Oxford: Osprey.

SAunders, A. 1998. The Defence of Britain Project, in A.J. Schofield (ed.) Monuments of war: the evaluation, recording and management of twentieth-century military sites: 7-9. London: English Heritage.

SCHOFIELD, J. 2001. D-Day sites in England: an assessment. Antiquity 75: 77-83.

- 2004. Modern military matters. Studying and managing the twentieth-century defence heritage in Britain: a discussion document. York: Council for British Archaeology.

- 2005. Combat archaeology: material culture and modern conflict. London: Duckworth.

Seitsonen, O. \& V.-P. Herva. 2011. Forgotten in the wilderness: WWII German PoW camps in Finnish Lapland, in A. Myers \& G. Moshenska (ed.) Archaeologies of internment: 171-90. London: Springer. http://dx.doi.org/10.1007/ 978-1-4419-9666-4_10

SteinweG, B. \& M. KerTH. 2013. Kriegsbeeinflusste Böden; Böden als Zeugen des Ersten und Zweiten Weltkrieges. Bodenschutz 2/2013: 52-57.

Vogel, R. 1994. Tactical air power in Normandy: some thoughts on the Interdiction Plan. Canadian Military History 3(1): 37-47.

WEgENER, W. 2006. Vorstellung Vogelsang-der Westwall im Bereich Nationalpark Eifel. Archäologie im Rheinland 2006: 219-21.

- 2011. Schlachtfeld-Archäologie, in Konejung Stiftung Kultur (ed.) Archäologischer Wanderweg Hürtgenwald 1944-45 (Flyer 94).

Vettweiss-Müddersheim: Konejung Stiftung Kultur. Available at: http://www.rureifel-tourismus.de/ fileadmin/data/Downloads/Flyer-Archaeologischer. pdf (accessed 10 June 2014).

WOODWARD, R. 2014. Military landscapes: agendas and approaches for future research. Progress in Human Geography 38: 40-61. http://dx.doi.org/10.1177/0309132513493219

Zaloga, S.J. 2007. The Atlantic Wall (1): France. Oxford: Osprey.

ZetTerling, N. 2000. Normandy, 1944: German military organization, combat power and organizational effectiveness. Winnipeg: Fedorowicz.

Received: 7 August 2013; Accepted: 19 November 2013; Revised: 23 April 2014

(C) Antiquity Publications Ltd. 